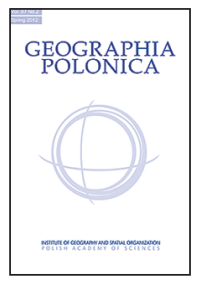 \\ INSTITUTE OF GEOGRAPHY AND SPATIAL ORGANIZATION \\ POLISH ACADEMY OF SCIENCES \\ www.igipz.pan.pl \\ www.geographiapolonica.pl
}

\title{
DISTRIBUTION OF POPULATION DENSITY IN POLISH TOWNS AND CITIES ${ }^{1}$
}

\section{Przemysław Śleszyński}

Institute of Geography and Spatial Organization

Polish Academy of Sciences

Twarda 51/55, 00-818 Warsaw: Poland

e-mail: psleszyn@twarda.pan.pl

\begin{abstract}
This article presents an analysis of the population-density distributions present in 147 Polish towns and cities of 30,000 inhabitants or more, as of 2002. The determination of these distributions was by reference to concentric rings $1 \mathrm{~km}$ across, with numbers of inhabitants being determined on the basis of aggregate data for 14,000 statistical districts, the numbers per centre ranging from 16 in the case of kuków to 1346 in Warsaw. The districts in question cover a total area of $9800 \mathrm{~km}^{2}$ and account overall for some 16.8 million inhabitants of Poland. This makes this the most exhaustive analysis of population-density distributions ever carried out for the country. The results of the analyses point to the widespread presence of function-related distributions of population density in the largest Polish cities, albeit irrespective of their size as referred to more precisely. A clear majority $(88 \%)$ of centres are characterised by a distribution model in line with either the exponential or power functions, or derivatives. The 'crater effect' indicative of depopulation in city centres is met with only rarely, in just a very few towns and cities, this perhaps reflecting the relative youthfulness of Poland's urban areas.
\end{abstract}

\section{Key words}

population density distribution - population density profile $\cdot$ population density model $\bullet$ urban population - Poland's cities

\section{Introduction}

The issue of the distribution and evolution of population configurations is one of those raised more regularly in the fields or urban geography and economics. In this regard, the most important of the regularities revealed and described is the distribution of popula- tion density in relation to distance from the centre. This distribution is non-uniform, but nevertheless mostly regular, and describable with the aid of different types of function,

1 This article is a slightly modified version of the one published in Polish by the Łódź University Press (Śleszyński 2011). 
most especially exponential and logarithmic functions (Fig. 1).

Mentioned above all as a classic study within the body of relevant literature is that by Clark (1951), who pioneered research into the population-density profiles of towns and cities as set against distances from their centres, these being defined as centres of gravity where functional structure is concerned (as for example from the points of view of transport, business or whatever). Other, modified methods were as proposed by Korzybski (1954) and Medvedkov (1963), though these have not gained any more greater renown away from just a small handful of countries (Poland among them). In general, work on population-density profiles, and more generally on population configurations in urbanised areas, is relatively plentiful, and has been concerned with countries of various different specifics from the socioeconomic and cultural points of view (see reference list). In line with methodological development, there has also arisen a concept whereby changes in population density are set in the broader context of the development of urban areas (Korcelli 1969, Mydel \& Ishimizu 1985). The concept has recently been invoked in the case of Poland by Stępniak (2012), the author revealing regularities to temporal/spatial phases in the concentration and deconcentration of housing construction in Warsaw between the end of the Second World War and today.

Early research into the towns and cities of Poland was done on the basis of a limited statistical base, hence a relatively limited degree of accuracy, though not one insufficient for certain of the most fundamental regularities to be identified (Bromek 1954). In contrast, the first more advanced and detailed analysis was that carried out by Kostrubiec (1970). In that work - whose subject was the Warsaw agglomeration - the method of the aforementioned Korzybski (1954) which was applied entailed the designation of the density profile, not from the centre of the functional configuration, but 'outward' from the place in which the population density was highest. Density of population itself was determined to be an excellent exponent measuring the density of

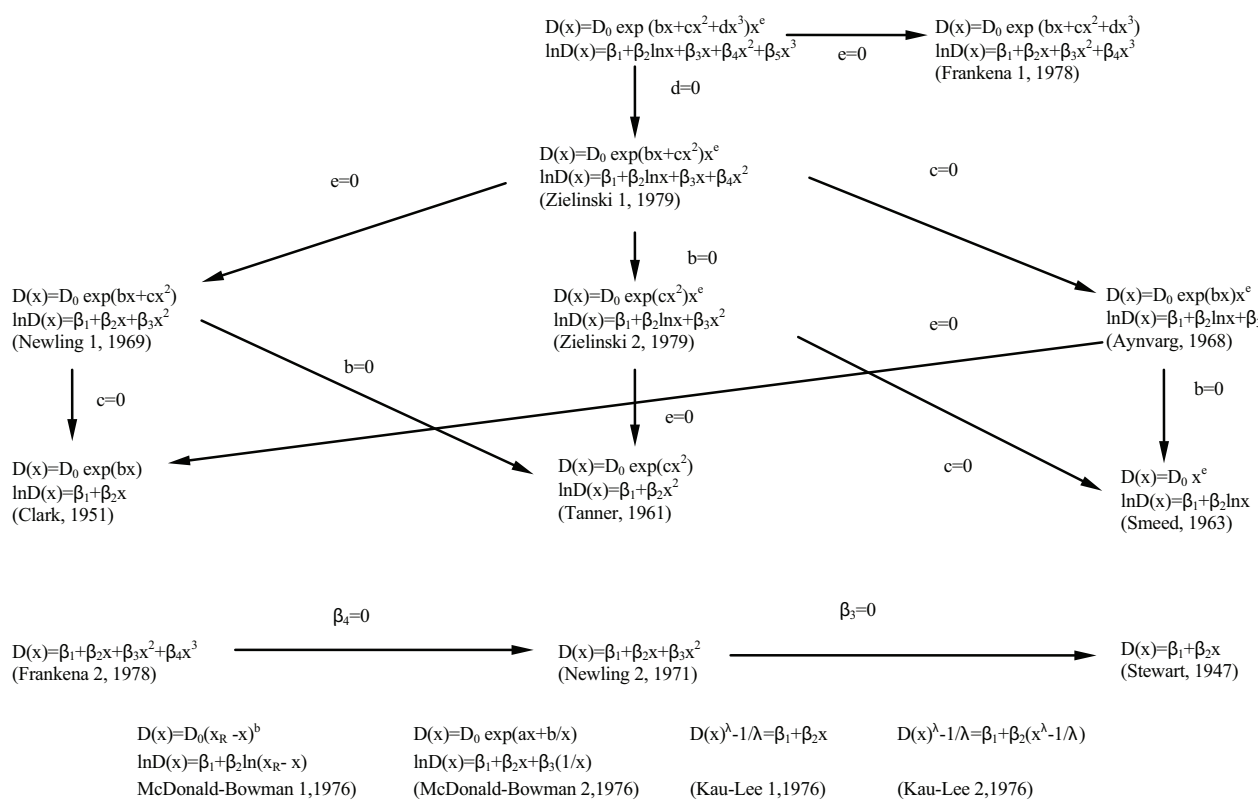

Figure 1. Classic functional forms assumed by population density profiles

Source: Martori and Suriñach 2001. 
development of an urban centre, as well as as a constant and stationary scalar field spread across the relevant area. In the case of the centre of Warsaw, work on the population-density distribution was later returned to by Lentz (1975; a comparative study with North American cities), Klimaszewska-Budzynowska (1977) and Śleszyński (2002). Other large Polish cities also became subject to similar research in the fullness of time, including Cracow (Mydel 1979) and Wrocław (Miszewska 1995).

The development of technologies for the gathering and processing of data currently allows for research to make exhaustive use of the databases concerning all of Poland's largest cities. However, a fundamental problem for the researcher, also brought into sharp relief in this study, is to explain whether within these sets there are the repeatable regularities to the development of population-density structures that have only been observed in a few cases up to now. Establishing this fact ought to be of importance when it comes to a better and fuller recognition and understanding of spatial structures, and the evolution of population configurations.

It is thus possible to formulate the main objectives of this study in line with questions regarding:

- the nature of the spatial structure to population density in the Polish towns and cities;

- regularities that may be present where the distribution of population is concerned;

- the possibility or non-possibility of these regularities relating to model configurations;

- possible linkage between the aforementioned regularities and town or city locations, demographic sizes or administrative ranks.

\section{The source data and their processing}

The methodology of the cartographic and statistical analysis of diffuse phenomena and their graphic presentation are among the best-developed aspects of spatial studies. One of the basic circumstances influencing the precise calculation of population-density profiles is the accessibility of detailed databases concerned with the real distribution of population. The work described here made use of the base comprising the statistical districts into which the towns and cities of Poland with more than 30,000 people are divided, in line with the situation at the time of the 2002 Census. 147 such towns and cities were identified, and together these represent almost all of the more major regional, sub-regional and local centres thus representing the basic skeleton supporting the overall settlement network nationally. Together these centres extend across some 14,000 of the aforementioned statistical districts, with a total population of $9800 \mathrm{~km}^{2}$ and some 16.8 million inhabitants. In the devised base there were the greatest numbers of districts falling within the area of Warsaw (1346), and the fewest in Łuków (19). 2079 of the districts cover more than $1 \mathrm{~km}^{2}$, while no fewer than 6353 have areas below $0.1 \mathrm{~km}^{2}$. This is a level of detail making possible analysis of population-density profiles accurate to the nearest $0.5-1 \mathrm{~km}$.

The original base contained information on numbers of permanent inhabitants (the definition of a resident in the meaning of the Census was presented in exhaustive detail in the relevant methodological explanations, GUS 2003). From the point of view of intraurban analyses, it is only worth noting that the data in question do not take in all the people who are truly resident, but do nevertheless offer a better qualitative and quantitative representation of the circumstances than do, for example, the register of residents kept at district level, or the PESEL database of personal identification numbers, both of which are based to some extent around the statistics kept on registration and deregistration in given localities.

It is worth noting that the differences between distributions in respect of people who are registered in a given area or else actually living in them may be relatively large in Poland, in line with the fact that the obligation to register is not widely adhered to, all the more so given regular rumours to the effect 
that the obligation will soon be lifted anyway. Other research reports that the net impact of the under- and overestimations arising out of comparisons between addresses for the purpose of correspondence and registration in Warsaw is of $+6.6 \%$. This translates into the Polish capital being resided in by some 113,000 people more than the official data suggest (Śleszyński 2011)². Still other estimates obtained using a quite distinct methodology suggest that the Warsaw population may be being underestimated to the tune of some 220,000-250,000 people (Bijak et al. 2007; Śleszyński 2012).

This ought not to have too great a significance in regard to this particular study, since even a $10 \%$ difference does not impact in any more fundamental way upon the shapes of curves modelling population-density profiles. It is further assumed that, even where a given person does not necessarily reside at the officially recognised address, the place of that person will have been taken by someone else, this therefore making good the statistical deficit. It is likewise worth stressing that the census data made use of very much confirmed figures from ongoing registrations, only being greater in the case of Warsaw by around 70,000 people (Śleszyński 2005).

Bearing all this in mind, the basic information regarding registered (official) population density in towns, cities and statistical districts is as follows:

- the typical density is of 1721 people per $\mathrm{km}^{2}$, while the arithmetic mean for all statistical districts is 14,337 per $\mathrm{km}^{2}$, and the median 10,222 people per $\mathrm{km}^{2}$;

- only $0.7 \%$ of the inhabitants of the towns and cities analysed occupy statistical districts with population densities below 100 people per $\mathrm{km}^{2}$, while there are 10.9\% residing at densities in the range 100$1000,34.3 \%$ at densities of between 1 and 10,000 and $54.2 \%$ at densities in excess of 10,000 people per $\mathrm{km}^{2}$;

\footnotetext{
2 Moreover, in other selected towns and cities of central Poland the values were: Radom (-0.4\%), Płock $(-0.2 \%)$ and Ostrołęka (-1.7\%).
}

- analogous indicators calculated for the administrative areas of towns and cities are in turn: $22.3 \%$ by area with population densities up to 100 people per $\mathrm{km}^{2}, 54.3 \%$ - 100-1000, $18.8 \%$ - 1-10,000 and $4.7 \%$ over 10,000 .

The central points of towns and cities were designated for the purposes of the analysis, these usually taking the form of a market square, the junction between two main streets, the centre of gravity of a transport system, and so on. Use was thus made of available up-to-date information, including of a topographical nature. In the case of conglomerate cities it was the midpoint of the larger centre that was designated. Data on numbers of inhabitants in statistical districts were then recalculated for zones of concentration of radius $0.5 \mathrm{~km}$, delineated outwards from the centres of towns and cities (with some analysis also making use of $1 \mathrm{~km}$ intervals). The means of aggregation was in this way proportional to the area of the statistical district found within the given concentration zone. This is something of a simplification, since it is almost always the case that a given statistical district - however small a unit that may be - is not inhabited evenly across its area. This is especially true of the districts located in the external zones of cities with an overall large share of green space, including even farmland and forest. The low values for numbers of inhabitants in these areas - as compared with centres - should not nevertheless be the cause of any more major errors.

To meet the needs of the analysis, several means of categorising towns and cities were employed. In the first place, populationdensity distributions were analysed with respect to the numbers of inhabitants of the given centre. The assumption proceeded upon in this case was that a greater concentration of numbers of inhabitants should be in a position to exert greater pressure as regards investment and habitation, with the result that the density of population rises further. In the second place, use was made of hierarchical categorisation of urban centres 
in Poland, related to administrative division and position in settlement system. This categorisation gave rise to the following five groups in respect of the 147 towns and cities analysed:

A - the so-called MEGA (Metropolitan European Growth Areas) group of 8 main metropolitan centres (Warsaw, Szczecin, Gdańsk, Poznań, Łódź, Wrocław, Katowice and (racow);

B - 14 regional centres (all the remaining voivodship-level centres, plus Radom, Częstochowa, Bielsko-Biała and Rybnik)3;

C - 29 more important sub-regional centres (cities that are simultaneously urban poviats or were once capitals of voivodships when there were 49 of these, as opposed to the present 16);

D - 59 other sub-regional centres (other towns outside agglomerations with more than 30,000 inhabitants);

E - 36 towns and cities located within mono- or polycentric agglomerations (i.a. Gdynia, Sopot, Police, Sosnowiec, Gliwice, Zabrze, Bytom, Żory, Mysłowice, Legionowo, Sopot and Świdnik).

\section{Models for the distribution of population density}

Generalised distributions of population density for all of the towns and cities considered are as presented in Figure 2. The match obtained was with an exponential function, for which the coefficient $R^{2}$ was of 0.925 , i.e. a high value. This therefore denotes an answer in the affirmative for the question regarding some overall regularity to the distribution of population densities in Polish towns and cities. Moreover, as the figure makes clear, it is typical for a distance some 3.0-3.5 km out from the centre to be associated with a change taken in the course of the density profile. The distribution of points on

\footnotetext{
3 According to certain Polish classifications, some of the cities in this category are termed metropolises (as especially in the cases of Lublin and Bydgoszcz-Toruń) - however, from the point of view of the subject of this article this is of secondary importance.
}

the figure also points to characteristic blips or jumps affecting the way densities change at distances of $6.5,9,11$ and $16 \mathrm{~km}$. Between these points, the curve takes the form of an arc bent slightly downwards. It is hard to say at this point whether this is a more general regularity or merely a coincidence.

By breaking down the set of towns and cities analysed into categories distinguished in line with administrative and settlementrelated features (the hierarchy of this type), it proves possible to uncover certain disparities (Fig. 3). What is generally observable is that the level of match as compared with the ideal course taken by curves is lower further down the hierarchy in question. Given that the categories lower down are ones that are better represented, the scope to this nonregularity would seem to be all the more important. Overall, there is relatively the best fit in regard to category A urban centres (i.e. metropolitan centres), as well as the worst fit in regard to towns of categories D (lesser subregional centres) and $E$ (towns within monoand polycentric agglomerations).

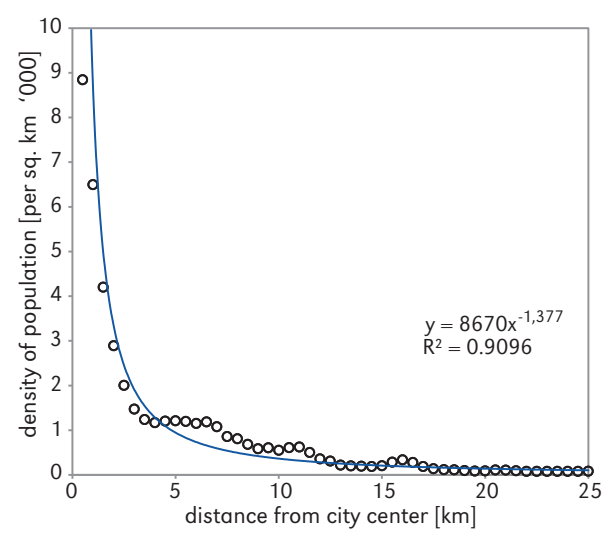

Figure 2. Generalised population-density distribution in 2002, for all 147 studied towns in concentric zones delimited at $0.5 \mathrm{~km}$ intervals

Most of the cities assigned to the metropolitan centres category are found to be characterised by an exponential model for the population-density distribution. There is particularly close agreement with this function in the cases of Warsaw, Wrocław and Gdańsk. 
In contrast, in the case of Szczecin, the most suitable model proved to be that based on a power function. What is interesting is that it is in this very city that the highest city-centre population density is to be noted, in excess of 20,000 people per $\mathrm{km}^{2}$.

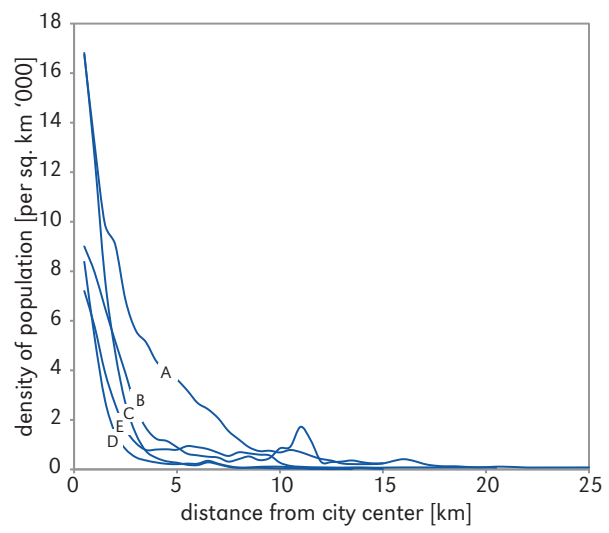

Figure 3. Population-density distributions for the five studied categories of urban centre (A-E)

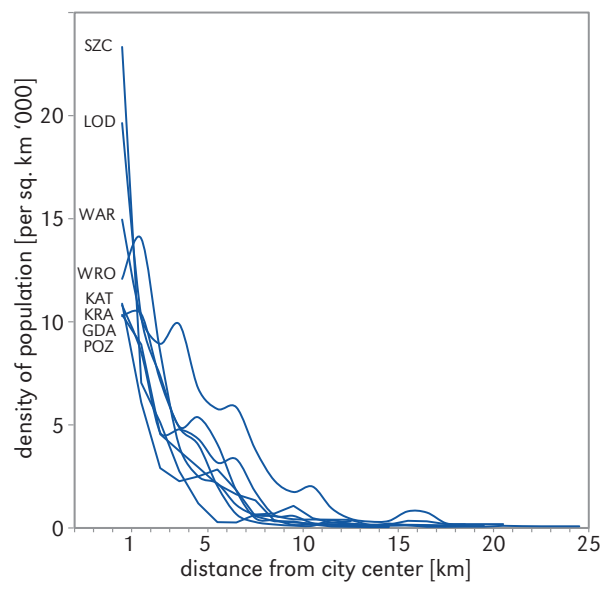

Figure 4. Distribution of population density in the cases of 8 metropolitan centres (MEGA) as of 2002. SZC - Szczecin, LOD - Łódź, WAR - Warsaw, WRO - Wrocław, KAT - Katowice, KRA

- Cracow, GDA - Gdańsk, POZ - Poznań

Where the regional cities are concerned most of the population-density distributions relate to the exponential or power models. What was characteristic in this respect was the rapid decline in density with successively greater distances from centres. However, in the cases of some urban centres there were marked departures from a steady fall in the outward direction. For example, Bydgoszcz had a distinct increase in the density of population around $11-12 \mathrm{~km}$ out from the centre - up to a value of around 3000 people per $\mathrm{km}^{2}$. This reflects the presence of a concentration of housing estates in Fordon district.

In general, regional cities are characterised by lower values for population density. The level of 10,000 people per $\mathrm{km}^{2}$ in centrally-located rings is only found to be exceeded in Toruń, Białystok and Radom.

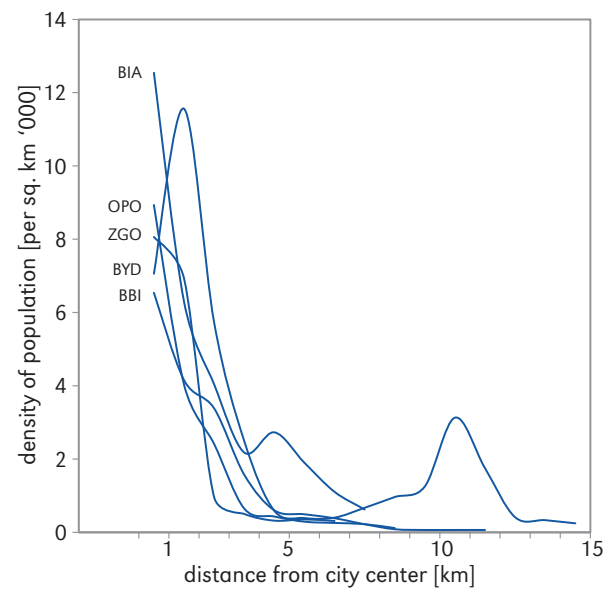

Figure 5. Population-density distributions for cities selected from among the 14 regional centres as of 2020. BIA - Białystok, OPO - Opole, ZGO - Zielona Góra, BYD - Bydgoszcz, BBI - Bielsko-Biała

The more important regional centres were characterised by lower values for population density, and an even more marked fall-off in these with distance from the centre. The highest population densities (above 10,000 people per $\mathrm{km}^{2}$ ) were to be noted in Konin, Płock and Legnica, while somewhat lower values (in the range $9000-10,000$ people per $\mathrm{km}^{2}$ ) characterised Włocławek, Słupsk and Ostrołęka. Beyond that, a feature here involved relatively large shares being accounted for by irregularities or anomalies in distribution visible in the courses assumed by the density profiles. This again reflects concentrations of large post-War housing estates located in the outer 
zones of towns and cities as processes of urbanisation and industrialisation continued.

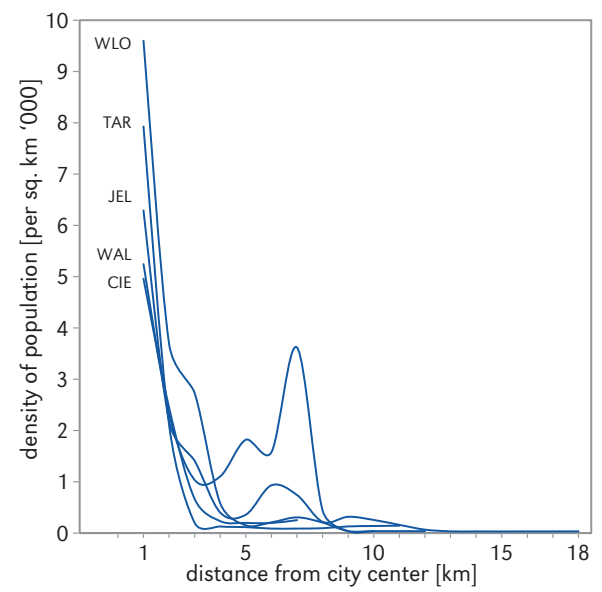

Figure 6. Population-density distributions for towns and cities selected from among the 29 more important sub-regional centres as of 2002. WLO - Włocławek, TAR - Tarnów, JEL - Jelenia Góra, WAL - Wałbrzych, CIE - Ciechanów

In the smaller sub-regional centres, a decline in population density was usually found to arise at distances some $3 \mathrm{~km}$ from the centre, the drop in question being from around $5000-7000$ people $\mathrm{km}^{2}$ to a stabilised 200-500 people in the concentric rings located further out. In the case of these centres too, it was quite typical to note anomalies - in the sense that values for population density might actually be higher once again in rings of the outer zone. Again, almost all of these non-regular circumstances reflected the locating of large-scale post-War housing estate of residential blocks.

The last category to be distinguished comprises towns located within very complex settlement configurations (i.e. mono- or polycentric agglomerations). These cases were characterised by the most irregular density profiles, in which there might be marked 'jumps' in density with increased distance from a centre. Such phenomena were particularly typical for the towns and cities in the Upper Silesian (Katowice) conurbation, in which the history of changes in the settlement network and urban-planning configura- tions is particularly complex. This is ultimately a reflection of the fact that this region was already quite densely populated by the Middle Ages, the ongoing urbanisation processes tending to result in already-developed smaller centres being absorbed into (incorporated by) larger ones.

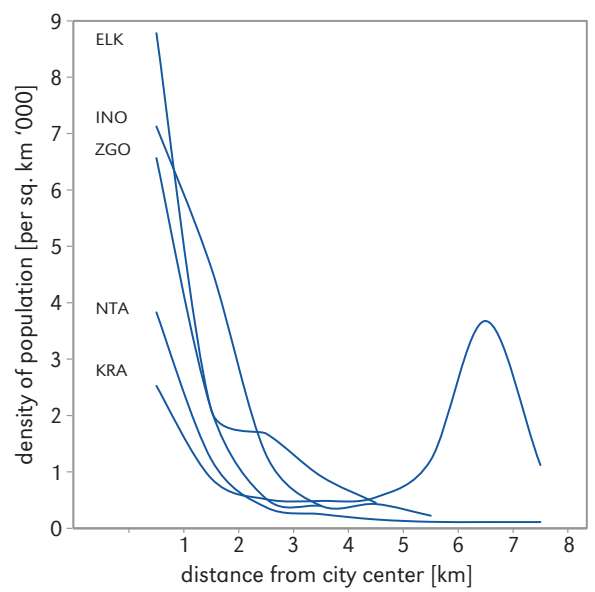

Figure 7. Population-density distributions for towns and cities selected from among the 60 sub-regional centres as of 2002. ELK - Ełk, INO - Inowrocław, ZGO - Zgorzelec, NTA - Nowy Targ, KRA - Kraśnik

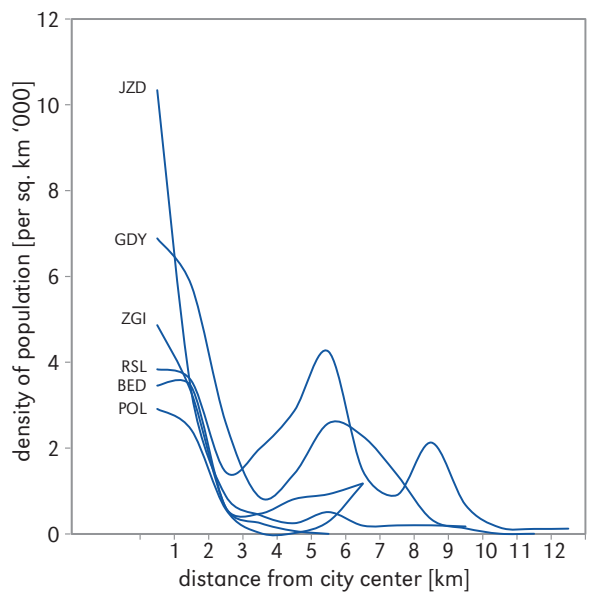

Figure 8. Population-density distributions for towns and cities selected from among the 36 located in mono- or polycentric agglomerations as of 2002. JZD - Jastrzębie-Zdrój, GDY - Gdynia, ZGI - Zgierz, RSL - Ruda Śląska, BED - Będzin, POL - Police 


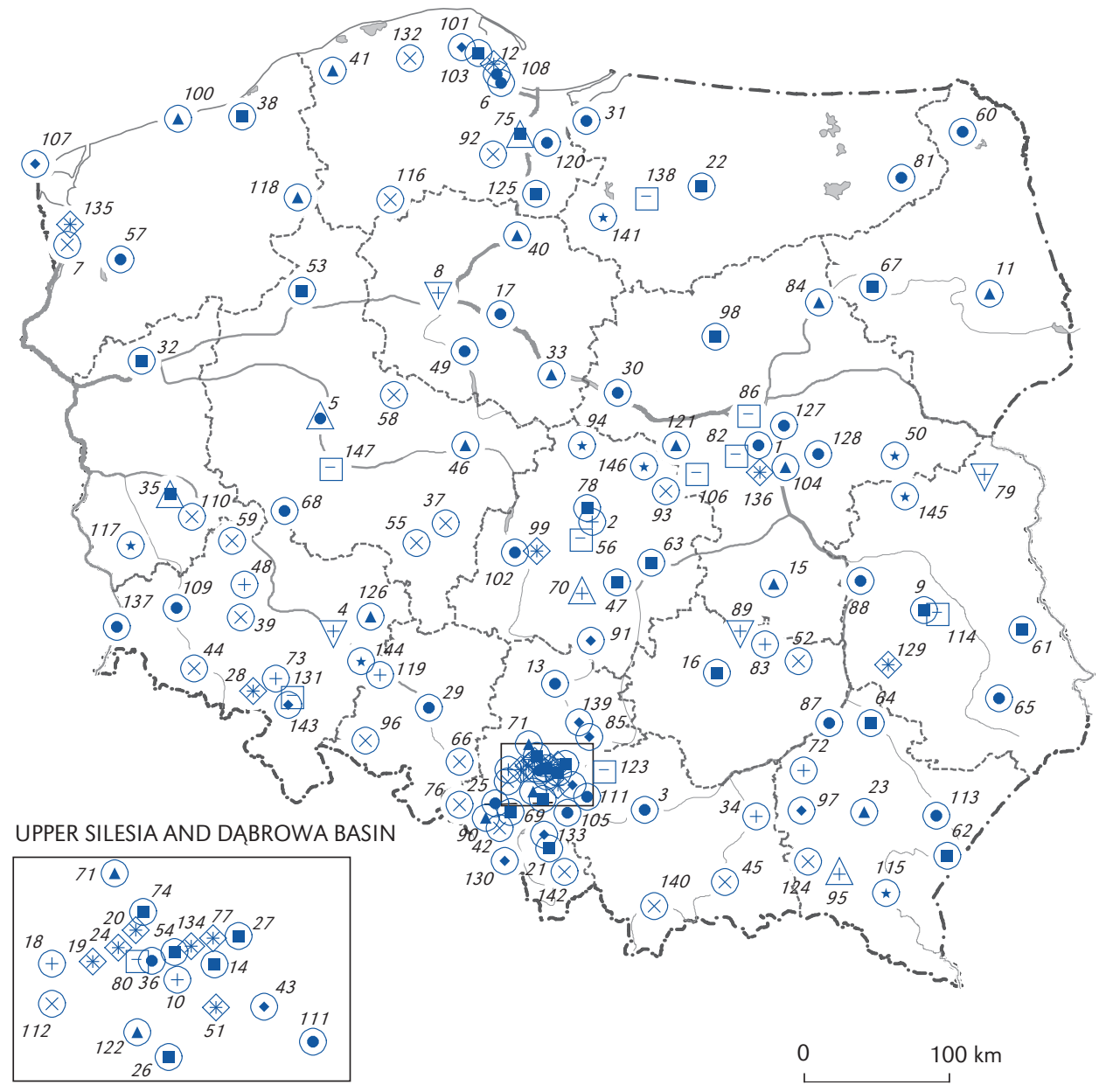

TYPE OF POPULATION DENSITY DISTRIBUTION

intensive growth (129)

\section{FITTING FUNCTION}

$\square$ extensive growth

- exponential fit (31)

$+\quad$ MMF/Weibull model (17)

$\triangle$ stagnate (5)

- geometric fit (30)

$\times \quad$ power fit (23)

$\nabla$ expiration ('crater') (4)

- Harris model (11)

\ Hoerl model (18)

$\star \quad$ heat capacity model (8)

* irregular (18)

$\diamond \operatorname{chaotic}(18)$

- linear fit (11)

Figure 9. A typology of Polish 147 towns and cities of over 30,000 inhabitants in regard to the nature of the distribution and the matching function for the density profile noted in 2002. Given in parenthesis are the numbers of incidences of each kind noted. Abbreviation:1 - Warsaw, 2 - Łódź, 3 - Cracow, 4 - Wrocław, 5 - Poznań, 6 - Gdańsk, 7 - Szczecin, 8 - Bydgoszcz, 9 - Lublin, 10 - Katowice, 11 - Białystok, 12 - Gdynia, 13 - Częstochowa, 14 - Sosnowiec, 15 - Radom, 16 - Kielce, 17 - Toruń, 18 - Gliwice, 19 - Zabrze, 20 - Bytom, 21 - Bielsko-Biała, 22 - Olsztyn, 23 - Rzeszów, 24 - Ruda Śląska, 25 - Rybnik, 26 - Tychy, 27 - Dąbrowa Górnicza, 28 - Wałbrzych, 29 - Opole, 30 - Płock, 31 - Elblą, 32 - Gorzów 


\section{The classification of towns and cities}

A further stage in the analyses carried out entailed the development of a typology for towns and cities based on the course of population-density distributions, as well as matching functions. The classification procedure used best-fits between given density profiles and one or other of the curves. The results are as mapped in Figure 9.

A clear majority of the urban centres (almost 90\%) were of a population-density distribution type in which there was a marked gradient entailing increased density of population with ever-closer approach to the townor city-centre area. This was termed the intensive increase type, and most cases of it were found to constitute population-density distributions in line with functions arising out of exponential or power models. This was true of more than $70 \%$ of the centres assigned to this group, including Warsaw. As is well-known, this kind of distribution is true of urban centres at relatively early stages of development. Otherwise these are centres with a relatively long past, but ones in which there are either constant natural increases (reflecting migration) or maintained concentrations of population in the central area, notwithstanding trends towards deconcentra- tion that may be operating. This explains the presence within this category of both some of Poland's oldest urban centres (Cracow, Sieradz, Płock and Częstochowa), and some centres that developed markedly after the Second World War (Białystok, Olsztyn, Konin and Nowy Targ).

Withinthe category described it is furtherpossible to identify a hyperintensive sub-type (not indicated on the map, but taking in some 20 urban centres). In these, the increase in values for population density towards the centres is particularly marked, sometimes even 5-8 times higher than in an adjacent concentric ring (as in Konin, Ostrołęka, Świnoujście, Bielawa and Mikołów). In most of these cases the functions modelling the courses of the population-density curves most effectively were Harris or Hoerl functions.

The extensive increase type was identified where the change in the population-density gradient displayed direct proportionality, and was therefore well modelled by means of a linear function. There were 11 towns of cities of this kind, including Legionowo, Żyrardów, Olkusz and Pabianice. A proportional decrease in population density in line with distance from a centre attests to a certain monotony to the forces shaping functional and spatial structure, both centrifugally and centripetally. In the case of the latter this

Wielkopolski, 33 - Włocławek, 34 - Tarnów, 35 - Zielona Góra, 36 - Chorzów, 37 - Kalisz, 38 - Koszalin, 39 - Legnica, 40 - Grudziądz, 41 - Słupsk, 42 - Jastrzębie-Zdrój, 43 - Jaworzno, 44 - Jeleinia Góra, 45 - Nowy Sącz, 46 - Konin, 47 - Piotrków Trybunalski, 48 - Lubin, 49 - Inowrocław, 50 - Siedlce, 51 - Mysłowice, 52 - Ostrowiec Świętokrzyski, 53 - Piła, 54 - Siemianowice Śląskie, 55 - Ostrów Wielkopolski, 56 - Pabianice, 57 - Stargard Szczeciński, 58 - Gniezno, 59 - Głogów, 60 - Suwałki, 61 - Chełm, 62 - Przemyśl, 63 - Tomaszów Mazowiecki, 64 - Stalowa Wola, 65 - Zamość, 66 - Kędzierzyn-Koźle, 67 - Łomża, 68 - Leszno, 69 - Żory, 70 - Bełchatów, 71 - Tarnowskie Góry, 72 - Mielec, 73 - Świdnica, 74 - Piekary Śląskie, 75 - Tczew, 76 - Racibórz, 77 - Będzin, 78 - Zgierz, 79 - Biała Podlaska, 80 - Świętochłowice, 81 - Ełk, 82 - Pruszków, 83 - Starachowice, 84 - Ostrołęka, 85 - Zawiercie, 86 - Legionowo, 87 - Tarnobrzeg, 88 - Puławy, 89 - Skarżysko-Kamienna, 90 - Wodzisław Śląski, 91 - Radomsko, 92 - Starogard Gdański, 93 - Skierniewice, 94 - Kutno, 95 - Krosno, 96 - Nysa, 97 - Dębica, 98 - Ciechanów, 99 - Zduńska Wola, 100 - Kołobrzeg, 101 - Wejherowo, 102 - Sieradz, 103 - Rumia, 104 - Otwock, 105 - Oświęcim, 106 - Żyrardów, 107 - Świnoujście, 108 - Sopot, 109 - Bolesławiec, 110 - Nowa Sól, 111 - Chrzanów, 112 - Knurów, 113 - Jarosław, 114 - Świdnik, 115 - Sanok, 116 - Chojnice, 117 - Żary, 118 - Szczecinek, 119 - Brzeg, 120 - Malbork, 121 - Sochaczew, 122 - Mikołów, 123 - Olkusz, 124 - Jasło, 125 - Kwidzyn, 126 - Oleśnica, 127 - Wołomin, 128 - Mińsk Mazowiecki, 129 - Kraśnik, 130 - Cieszyn, 131 - Dzierżoniów, 132 - Lębork, 133 - Czechowice-Dziedzice, 134 - Czeladź, 135 - Police, 136 - Piaseczno, 137 - Zgorzelec, 138 - Ostróda, 139 - Myszków, 140 - Nowy Targ, 141 - Iława, 142 - Żywiec, 143 - Bielawa, 144 - Oława, 145 - Łuków, 146 - Łowicz, 147 - Śrem 
probably reflects the proximity of other large centre, since many of the urban centres of this type are indeed 'in the shadow' of the cores of the largest agglomerations.

The stagnating type is manifested in a 'flattening' of the observed values for population densities in the concentric rings found closest to the centre. This may otherwise be seen as a mature phase under the classic formula from R. Newling (1969), which is characteristic for centres noting enhanced deconcentration of central areas. A distribution of population density whereby values become similar in two or three of the first zones out from the central point was only found to characterise the 5 centres of Poznań, Zielona Górę, Krosno, Bełchatów and Tczew. In this case the best fit was with MMF (sigmoid or S-shaped) functions, or else Weibull functions or vapor preassure.

The expiring type (popularly considered to be characterised by a central 'crater') was also a rarity, being found to characterise just the 4 urban centres of Wrocław, Bydgoszcz, Skarżysko-Kamienna and Biała Podlaska. The function offering the best match here was often the MMF or Weibull model.

Proving unsuited to any unambiguous description were cases of population-density distribution assigned to the disorderly type. These are generally conglomerate-towns or centres within larger mono- or polycentric systems, most especially the Katowice conurbation, or that of Rybnik. The category also includes satellite towns around a monocentric agglomeration (Police). Moreover, there were several towns displaying a Gaussian distribution (bell curve). However, it is important to note that in these cases the course of curves could not be well-matched to values observed, it thus being necessary to classify the urban centres of this kind into a category including non-regular distributions

\section{Regularities to density distribution}

Population densities in the towns and cities studied were set against selected demographic features. The overall mean density of population was not investigated (regularities in this regard having been described exhaustively by Szymańska et al. 2009). Rather, the focus was on indicators representative of areas closest to the designated central points. What was tested, in other words, was the hypothesis holding that there is a link between population density in central parts and demographic features of urban areas taken overall.

The results of some of the regression analyses are presented in Figure 10. It was possible to note the following (statistically significant) co-occurring elements where density of population in the $0-2 \mathrm{~km}$ concentration zone was concerned:

- a rather strong link with the demographic sizes of towns or cities;

- a weak link with the share of the population that is of post-productive age.

The correlation between the degree of concentration of population in the central area and the overall population was also investigated, and the results of the relevant analyses in this case reveal:

- a weak link with the demographic sizes of towns and cities;

- a weak link with the share of the population that is of productive age.

How can the results obtained be interpreted? First and foremost, caution needs to be applied in drawing any conclusions as regards interdependence between the development of the distribution and demographic structure in the areas of Polish towns and cities. The known link between demographic age and the size of a given urban centre is not always sustained by earlier processes whereby the degree to which configurations are densely populated increases towards the centre. A matter of key significance here would appear to be the uneven nature of rates of socieconomic development in Polish urban centres, disrupted as these were by depopulation processes induced by the Second World War, along with marked later relocations of population. In contrast, a positive correlation between the size of a town or city and the intensity with which population is distributed across the central area 

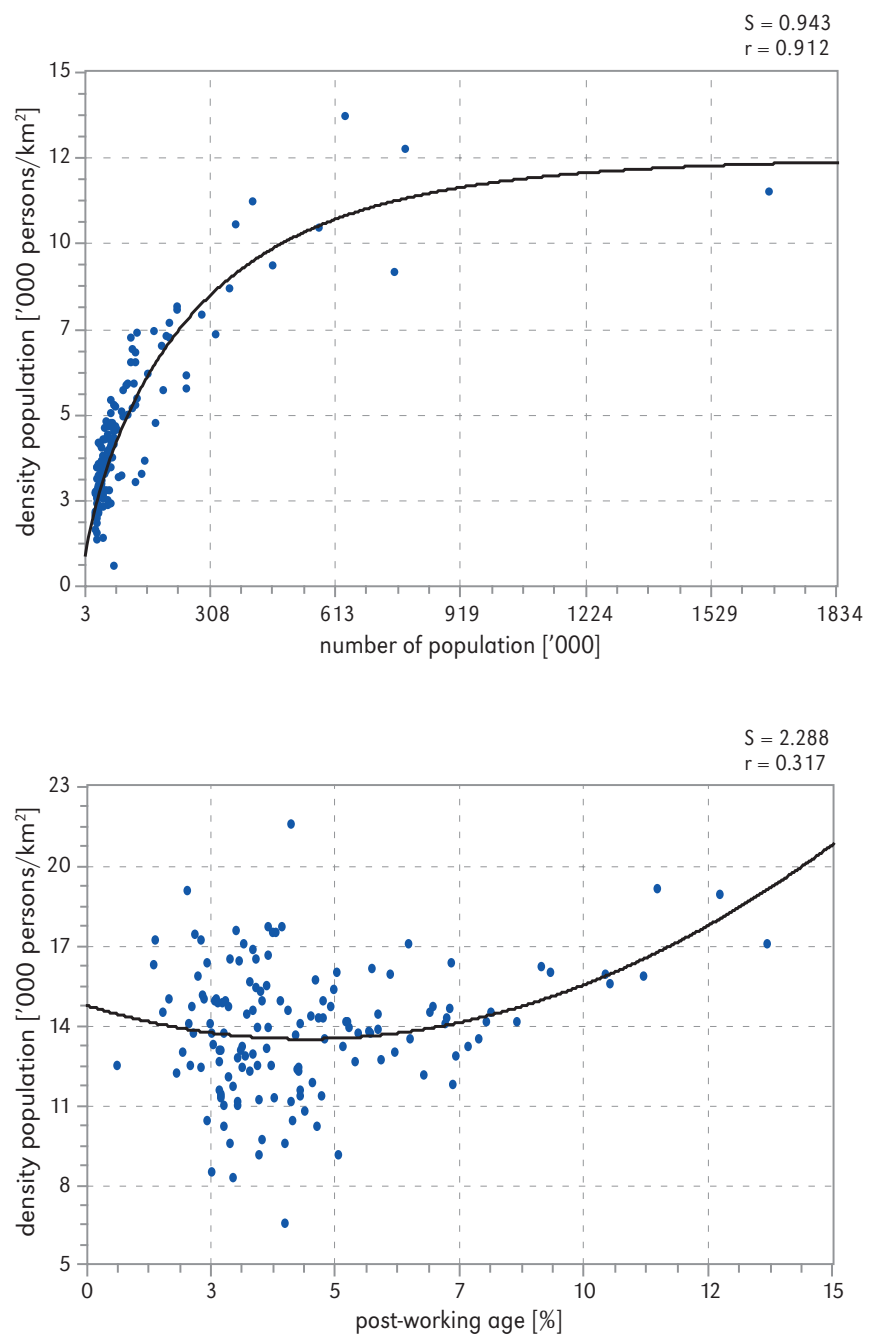

Figure 10. Statistical relationships between the population density of central areas and demographic variables, i.e. the number of inhabitants of the town or city as a whole and the share of the population accounted for by people of post-working age. Relationship with the number of inhabitants: Weibull model: $y=a-b^{\star} \exp \left(-c^{\star} x^{d}\right) ; a=12.362, b=11.689, c=0.010771, d=0.8059$. Relationship with the share of a given city's inhabitants that are of productive age: quadratic function, $y=a+b x+c x^{2} ; a=15.080$, $b=-0.5929, c=0.06756$

points to some kind of proportional influence of centrifugal forces on the shaping of the population configuration. This means that a knowledge of the number of inhabitants is associated with predictions of maximal values for population density in the central area that enjoy a high probability of being correct.

\section{Conclusions}

From the cognitive point of view what is most important is the confirmation of the functional distribution of population density in the larger Polish cities, irrespective of their precise sizes. It may further be concluded that the development of population-density 
configurations in urbanised areas is governed by an overriding regularity associated with such an operation of centrifugal force as can give rise to an increase in the density of settlement of a regular and proportional nature when set against distance from the centre. It emerges that, in the Polish case at least, this is very much independent of the rate of development of urbanisation processes. After all, it might have been presumed that the rapid industrialisation leading to major influxes of inhabitants observable after World War II (Gawryszewski 2005) would result in distortion of the model for the population-density distribution. In the event, it turns out that this has been only a limited influence on regularities as regards the courses of profiles. While it was obviously possible to anticipate that some of the directions would feature clear anomalies in the courses of curves, the overall picture in the concentration zones remains a rather undistorted one.

The research determined that a decided majority of Polish towns and cities (no fewer than $88 \%$ of those in the category of 30,000 inhabitants or more) are characterised by a distribution model matchable using an exponential or power function, or a derivative function. The closer to the centre one is, the more this translates into an ever-more intensive increase in the degree of concentration of the population. In contrast, it is rare to come across an example of non-regularity to the distribution, this being primarily conditioned by a location within the larger settlement networks, and most especially polycentric agglomerations.

The depopulation of city centres - whose effect is a course for the population-density profile that includes a 'crater' in the middle is only met with rather rarely, holding true for just a couple of Polish cities. Prevailing in line with this kind of argumentation is a concept which sees the development of urbanisation process assuming a quite different course in Poland from that seen in the most highlydeveloped countries in recent years (Korcelli et al. 2012). In the context of the Poland-wide settlement system it is certainly not possible to refer to deurbanisation. Rather, falls in the number of inhabitants noted in the last 2-3 decades in certain central areas need to be interpreted in terms of a weakening of the process whereby numbers of inhabitants become concentrated, rather than a typical depopulation of a city centre or inner-city area. However, one may not preclude the process in question gathering far greater strength within the foreseeable future, most especially given the quite unambiguous demographic forecasts for Poland, which assume even a $10 \%$ decline in the population of the country over the next three decades.

From the practical point of view, it is also worth pointing to the relatively low values for population density sometimes revealed for the central parts of Polish towns and cities. In most of the areas the average value for this indicator did not exceed 10,000 people per $\mathrm{km}^{2}$ - which is to say a value well under onetenth as great as may be noted in the highlypopulated cities of Asia or Latin America.

From one point of this represents a failing, since lower densities of population translate into extensive use (even sprawl), to the prolongation of commutes, and hence to a raising of operational costs, especially as regards infrastructure. However, from other points of view this a unique advantage allowing overpopulation to be avoided, and hence permitting the development of settlement layouts that are more in line with the principles of sustainable development. On the basis of examples from Western Europe, Kowalewski (2006) notes that it may be possible to plan human settlement up to and including those with an index of 20-25,000 people per $\mathrm{km}^{2}$, without a need to bear burdensome existential, transportrelated and environmental consequences.

On the downside, the contemporary crisis of spatial management in Polish towns and cities is made all the more tangible, this manifesting itself in particular in transport-related problems paradoxically reflecting the extensive kind of management pursued up to now.

It is possible to conclude by formulating a research postulate that might entail further studies being carried out within a dynamic 
(historical) configuration. Work done to date on population-density profiles - and more broadly on the structure to population configurations within urbanised areas - has been limited by the availability of statistical data for small spatial units. At the present moment the 2002 Census data are unfortunately the most recent available with such detailed disaggregation. While it had been foreseen that the computerisation of the means of obtaining data employed with the 2011 Census would produce groundbreaking change (Dygaszewicz 2008), the results were not unfortunately as foreseen, to the extent that there is even a growing chorus going as far as to criticise the very reliability of the core census data (Eberhardt 2012; Gołata 2013), mainly on account of the methodology applied. This suggests a need for other sources to be made use of, including the administrative ones based around the system of

\section{References}

Berry B.J.L., Simmons J.W., Tennant R.J., 1964. Urban population densities: Structure and change. Geographical Review, vol. 53, no. 3, pp. 389-405.

Bijak J., KiCInger A., KupIszewski M., Śleszyński P. (cooperation), 2007. Studium metodologiczne oszacowania rzeczywistej liczby ludności Warszawy. CEFMR Working paper, no. 2, Warszawa: Środkowoeuropejskie Forum Badań Migracyjnych i Ludnościowych, 76 pp., http://www. cefmr.pan.pl/docs/cefmr_wp_2007-02.pdf [8 January 2014].

BRUECKNER J.K., 1986. A switching regression analysis of urban population densities. Journal of Urban Economics, vol. 19, no. 2, pp. 174-189.

Chunshan Z., XueQIang X., 1998. Population distribution and its change in Guangzhou city. Chinese Geographical Science, vol. 8, no. 3, pp. 193-203.

Clark C., 1951. Urban population densities. Journal of the Royal Statistical Society. Series A, vol. 114, no. 4, pp. 490-496.
PESEL identification numbers, notwithstanding the fact that this is most likely far less accurate, and at the same time very capable of generating hard-to-interpret results where population-density profiles in the Polish towns and cities are concerned.

\section{Acknowledgments}

Thanks are owing to Ms Beata Zielińska, who did most of the technical work associated with the pinpointing of city centres and the designation of concentric circles around them, as well as carrying out the regression analyses.

Editors' note:

Unless otherwise stated, the sources of tables and figures are the author(s), on the basis of their own research.

Czochański M., Kowalski G., Przewłocki S., 1986. Mapa gęstości zaludnienia i rozmieszczenia mieszkańców na przykładzie miasta Łodzi. Zeszyty Naukowe Politechniki Łódzkiej. Budownictwo, no. 37, pp. 217-227.

Dygaszewicz J., 2008. Zastosowanie map cyfrowych $w$ spisach powszechnych. Wiadomości Statystyczne, no. 4, pp. 22-29.

EberHARDT P., 2012. Stopień trafności polskich prognoz demograficznych. Czasopismo Geograficzne, vol. 83, iss. 1-2, pp. 3-28.

GaWryszewski A., 2005. Ludność Polski w XX wieku. Monografie, vol. 5, Warszawa: Instytut Geografii i Przestrzennego Zagospodarowania PAN, 623 pp.

GotatA E., 2013. Spis ludności i prawda. Studia Demograficzne, vol. 1, no. 161, pp. 23-55.

Griffith D.A., Wong D.W., 2006. Modelling population density across major US cities: A polycentric spatial regression approach. Journal of Geographical Systems, vol. 9, no. 1, pp. 53-75.

Guoming D., Shuwen Z., Youquan Z., 2006. Character and causes of population distribution 
in Shenyang City, China. Chinese Geographical Science, vol. 16, no. 3, pp. 217-222.

GUS, 2003. Raport z wyników Narodowego Spisu Powszechnego Ludności i Mieszkań 2002, Warszawa: Główny Urząd Statystyczny, 147 pp.

KlimaszewsKa-BudzYnOwSKA O., 1977. Modele rozkładu gęstości zaludnienia Warszawskiego Zespołu Miejskiego w latach 1879-1970. Przegląd Geograficzny, vol. 49, no. 3, pp. 481-506.

KorCELLI P., 1969. Rozwój struktury przestrzennej obszarów metropolitalnych Kalifornii. Prace Geograficzne, no. 78, Warszawa: Instytut Geografii PAN, 124 pp.

Korcelli P., Grochowski M., Kozubek E., Korcelli-Olejniczak E., Werner P., 2012. Development of urban-rural regions: From European to local perspective. Monografie, vol. 14, Warszawa: Instytut Geografii i Przestrzennego Zagospodarowania PAN, 158 pp.

KorZYBSKI S., 1954. Le profil de densité de population dans l'étude des zones urbaines de Londres et de Paris. La Vie Urbaine-Urbanisme et Habitation. New Series, vol. 2, pp. 113-156.

Kostrubiec B., 1970, Badania rozwoju przestrzennego aglomeracji miejskiej metoda profilów. Przegląd Geograficzny, vol. 62, no. 2, pp. 235-248.

KoWALEWSKI A.T., 2006. Społeczne, ekonomiczne i przestrzenne bariery rozwoju zrównoważonego. Kraków: Instytut Rozwoju Miast, 269 pp.

KrZYWiCKA-Blum E., 2003. Agregacja danych punktowych i pól odniesienia a informacyjne własności map gęstości. Polski Przegląd Kartograficzny, vol. 35, no. 3, pp. 175-184.

Latham R.F., Yeates M.H., 1970. Population density growth in metropolitan Toronto. Geographical Analysis, vol. 2, no. 2, pp. 177-185.

LENTZ P.A., 1975. A model of residential structure in a socialist city. A case study of Warsaw. Geographia Polonica, vol. 31, pp. 65-97.

LONGLey P.A., MeseV V., 2002. Measurement of density gradients and space-filling in urban systems. Papers in Regional Science, vol. 81, no. 1, pp. 1-28.

MARSDEN B.S., 1970. Temporal aspects of urban population densities: Brisbane. Australian Geographical Studies, vol. 8, no. 1, pp. 71-83.

MARTORI J.-C., SURIÑACH J., 2001. Classical models of urban population density. The case of BarceIona Metropolitan Area. Zagreb: 41st Congress of the European Regional Science Association, 29 August-1 September 2001, http://www. researchgate.net/publication/23730354_Classical_models_of_urban_population_density._ The_case_of_Barcelona_Metropolitan_Area [6 February 2014].

MedvedKov J.W., 1963. Prilozhenya k nekatorym zadacham ekonomicheskoy geografi. Geograficheskiy Sbornik, vol. 1, pp. 47-64.

Millward H., Bunting T., 2008. Patterning in urban population densities: A spatiotemporal model compared with Toronto 1971-2001. Environment and Planning A, vol. 40, no. 2, pp. 283-302.

MiszewsKA B., 1995. Zmiany gęstości zaludnienia a sukcesja form użytkowania ziemi we Wrocławiu w latach 1970-1994. [in:] A. Jagielski (ed.), Zadania badawcze geografii społecznej i ekonomicznej w obliczu transformacji ustrojowej i restrukturyzacji gospodarczej. Wrocław-Szklarska Poręba [25-27 September] 1995 (conference papers), Wrocław-Szklarska Poręba: Uniwersytet Wrocławski, pp. 187-194.

Muniz I., Galindo A., Garcia M.A., 2003. Cubic spline population density functions and satellite city delimitation: The case of Barcelona. Urban Studies, vol. 40, no. 7, pp. 1303-1321.

Mydel R., 1979. Rozwój struktury przestrzennej miasta Krakowa. Wrocław: Komisja Nauk Geograficznych, Ossolineum, 131 pp.

Mydel R., IshimizU T., 1988. Evolution of socioeconomic structure of Japan's metropolitan areas. Prace Geograficzne, no. 79, Prace Instytutu Geograficznego UJ, 101, Zeszyty Naukowe UJ, 946, Kraków: Uniwersytet Jagielloński, $113 \mathrm{pp}$.

NewLING B.E., 1969. The spatial variation of urban population densities. Geographical Review, vol. 59, no. 2, pp. 242-252.

Small K.A., Song S., 1994. Population and employment densities: Structure and change. Journal of Urban Economics, vol. 36, no. 3, pp. 292-313.

Spallek W., 2002. Metody prezentacji gęstości zjawisk rozproszonych na mapach tematycznych. Polski Przegląd Kartograficzny, vol. 34, no. 1, pp. 11-21.

StepNIAK M., 2012. The spatial deconcentration of housing resources in Warsaw in the years 1945-2008. Geographia Polonica, vol. 85, no. 1, pp. 67-80. 
Szymańska D., Grzelak-Kostulska E., HoŁowiecKA B., 2009. Polish towns and the changes in their areas and population densities. Bulletin of Geography. Socio-economic Series, vol. 11, no. 11, pp. 15-30.

ŚLESZYŃSKI P., 2002. Delimitacja centrum Warszawy - problemy badawcze. [in:] G. Węcławowicz (ed.), Warszawa jako przedmiot badań w geografii społeczno-ekonomicznej, Prace Geograficzne, no. 184, Warszawa: Instytut Geografii i Przestrzennego Zagospodarowania PAN, pp. 65-101.

ŚLESZYŃSKI P., 2005. Różnice liczby ludności ujawnione $w$ Narodowym Spisie Powszechnym 2002. Przegląd Geograficzny, vol. 77, no. 2, pp. 193-212.

ŚLESZYŃSKI P., 2011. Rozkład gęstości zaludnienia w polskich miastach. [in:] S. Kaczmarek (ed.), Miasto. Księga jubileuszowa w 70. rocznicę urodzin Profesora Stanisława Liszewskiego, Łódź: Wydawnictwo Uniwersytetu Łódzkiego, pp. 65-80.

ŚleszYŃSKI P., 2012. Warszawa i Obszar Metropolitalny Warszawy a rozwój Mazowsza. Trendy Rozwojowe Mazowsza, vol. 8, Warszawa: Mazowieckie Biuro Planowania Regionalnego, $160 \mathrm{pp}$

ZBOROWSKI A., 2005. Przemiany struktury społeczno-przestrzennej regionu miejskiego w okresie realnego socjalizmu i transformacji ustrojowej (na przykładzie Krakowa). Kraków: Uniwersytet Jagielloński, 576 pp.

ZiELINSKI K., 1979. Experimental analysis of eleven models of urban population density. Environment and Planning A, vol. 11, no. 6, pp. 629-641. 
http://rcin.org.pl 